\title{
Utilization of a Solar Greenhouse as a Solar Dryer for Drying Dates under the Climatic Conditions of the Eastern Province of Saudi Arabia
}

\author{
Part I: Thermal Performance Analysis of a Solar Dryer
}

\author{
Emad A. Almuhanna \\ Department of Agricultural Systems Engineering, King Faisal University \\ PO box 3340, Hofuf 31982, Saudi Arabia \\ Tel: 966-5-0592-3428Ｅ-mail: ealmuhanna@kfu.edu.sa
}

$\begin{array}{lc}\text { Received: August 19, } 2011 & \text { Accepted: September 7, } 2011 \quad \text { Online Published: December 29, } 2011 \\ \text { doi:10.5539/jas.v4n3p237 } & \text { URL: http://dx.doi.org/10.5539/jas.v4n3p237 }\end{array}$

\begin{abstract}
The goal of this project was to evaluate the feasibility of using a solar greenhouse as a solar dryer for drying dates. We attempted to analyze the thermal performance and thermal balance of the solar greenhouse. An experimental gable-even span greenhouse (solar greenhouse) was installed at the experimental research station at King Faisal University (latitude $25.4^{\circ} \mathrm{N}$, longitude $49.6^{\circ} \mathrm{E}$, and altitude $142 \mathrm{~m}$ above sea level) and functioned during October 2010. We evaluated the thermal performance analysis of the solar greenhouse (active or dynamic system) based on the thermal balance equations. The obtained results revealed that the daily average solar energy available outside the solar dryers was $15.921 \mathrm{kWh}$, and $12.335 \mathrm{kWh}$ was available inside the solar greenhouse for an average effective transmittance of $77.48 \%$. Of the $12.335 \mathrm{kWh}$ available inside the solar greenhouse, $7.414 \mathrm{kWh}$ was converted into useful heat gain that could be used for the drying process, $3.947 \mathrm{kWh}$ was lost by conduction and convection, and $0.686 \mathrm{kWh}$ was lost by thermal radiation. The solar energy available inside the solar greenhouse produced a $14.1{ }^{\circ} \mathrm{C}$ increase in the inside air temperatures versus the outside temperature $\left(33.6^{\circ} \mathrm{C}\right)$ and reduced the relative humidity of the inside air versus the outside air $(35.3 \%)$ by $9.6 \%$. The daily average overall thermal efficiency of the solar greenhouse during the experimental period was $57.2 \%$. Consequently, $42.8 \%$ of the solar energy available inside the solar greenhouse was lost. The predicted thermal balance for the solar greenhouse was well validated with that measured during the experimental period $(r=0.999)$ indicating an excellent agreement.
\end{abstract}

Keywords: Solar dryer, Thermal performance, Date

\section{Introduction}

Most developing countries cannot produce enough food to meet their increasing populations. A considerable percentage of crop items produced in some of these areas deteriorate rapidly in quality after harvest due to poor or non-existent processing and storage facilities. Field losses are high because the crops are usually left to dry slowly in the fields under heavy attack by insects, rodents, and dust. The drying process is one of the most common applications of solar energy in sunny countries. In most of these areas, the general practice is to use natural sun drying for threshed or shelled crops. In this method, the crops are spread on a bare floor or by the sides of the road for drying. Many alternative energy sources can be used instead of fossil fuels. The decision of what type of energy source should be used must, in each case, be made on the basis of economic, environmental, and safety considerations.

Because of its desirable environmental and safety aspects, solar energy is widely used instead of other alternative energy forms even when the costs involved are slightly higher. Saudi Arabia as a developing country, and its geographical location offers a great amount of natural energy, including solar energy and heated air by solar energy, that can be used for heating or drying different agricultural products (Al-Amri, 1997). The benefits from the installation and operation of solar energy systems can be divided into three categories: energy saving, generation of job opportunities, and a decrease in environmental pollution (Dincer, 1999). Therefore, using solar energy can considerably reduce energy costs. The efficiency of a solar dryer depends on its type and model as 
well as on the rate of heat loss during operation (Timoumi et al., 2004). Experiments conducted in many countries have clearly shown that solar energy can effectively be used to dry agricultural crops (Sarsavadia, 2007). Using solar energy as a heat source for crop drying has received considerable attention in recent years due to the rapid escalation of fossil fuel cost and the possibility of shortage. Ways to capture and use solar energy have generally involved coupling air heating systems that employ flat-plate solar collectors to grain-drying systems (Sharma et al., 2009).

One of the most important potential applications of solar energy is the solar drying of agricultural products (grapes, dates, apricots, bananas, tomatoes, onions, and green beans). Radiant energy from the sun can be used in two ways: either to heat the ambient air in a solar air heater and use that air to dry the agricultural products or to heat the products directly through the absorption of solar radiation by the wet product. The second method is more economical and easier because no heat transfer losses occur. However, vegetables containing high amounts of vitamin A and other medicinal and herbal products must not be exposed to direct solar radiation (Joshi et al., 2004). Any direct exposure to the sun during a high-temperature day may cause hardening, whereby a hard shell develops on the outside of the agricultural products, trapping the moisture inside. The employment of a solar dryer taps into the freely available solar energy while ensuring good product quality via judicious control of the irradiative heat (Sharma et al., 2009). Dehydration is one of the oldest techniques used for the storage of food or agricultural products or to use the power found in their by-products (Montero, 2005). The drying process is a basic operation that consists of reducing the moisture of a product so that the final product presents very different characteristics from the initial one (Montero et al., 2010).

There are basically four types of solar dryers (Jairaj et al., 2009): (1) direct solar dryers, whereby products are exposed directly to solar radiation, (2) indirect solar dryers, by which the products are not exposed directly to solar radiation but the air heated by the solar radiation is made to flow through them, (3) mixed-mode dryers, in which the products are exposed directly to solar radiation and also to hot air flowing through them, and (4) hybrid solar dryers, as shown in Figure 1. In the natural circulation mode, air is heated and circulated through the products naturally by buoyant force, as a result of wind pressure, or a combination of both. In the forced circulation mode, motorized fans or pumps circulate the heated air. The use of exhaust fans to expel the hot, moist air limits the increase in inside air temperature to only $7-9^{\circ} \mathrm{C}$ (under forced convection mode) This increase in the inside air temperature is generally insufficient for effective crop drying, and the crop takes a comparatively longer time to reach the desired moisture content of the dried product (Sethi and Sharma, 2007).

There is limited information on the utilization of an experimental greenhouse as a solar collector (solar air heaters) under the conditions found in the eastern province of Saudi Arabia. The variability and time-dependent characteristics of solar radiation make storage necessary for continuous operations in food drying. Thermal storage during the day can be used as a heat source during the night, through the operation of a solar assisted dryer, for continued drying of agricultural products. This process prevents re-hydration from the surrounding air (Aboul-Enein et al., 2000; Jain and Jain, 2004). Continuous drying also prevents microbial growth during drying (Hossain and Gottschaslk, 2006). Storage with an auxiliary heat supply can be used to assess the compatibility of the solar energy to meet the drying process temperature (Vlachos et al., 2002). The advantage of storing solar heat for several weeks for use in grain drying was to allow the drying process to proceed independently of the fall weather conditions and allow management flexibility in harvesting and drying the crops. The major disadvantage was that it required more hardware in the form of a large heat-storage structure and heat recovery equipment, which could lead to excessive cost. Some hybrid dryers were developed to control the drying air conditions throughout the drying time regardless of amount of sunshine and especially at night when it is not possible to use solar energy. Koyuncu (2006) tested the behavior of various designs of flat-plate, low-temperature air-heating solar collectors for crop drying applications. Ekechukwu (1999) and Ekechukwu and Norton (1999a, 1999b) presented an overview of drying principles and theory, solar drying technologies, and a description of low- temperature air-heating solar collectors for crop drying applications.

The main objective of this research was to utilize the solar greenhouse as a solar air heater for drying dates during October 2010. The objectives of this study are to analysis the thermal performance of the solar greenhouse, including air temperature rise, overall thermal efficiency, and thermal balance. To fulfill these objectives, a series of experiments were performed over five successive days in October 2010 at the Agricultural and Veterinary Research Station of King Faisal University.

\section{Materials and Methods}

\subsection{Solar Greenhouse (gable-even span type)}

An experimental gable-even span greenhouse (solar dryer) was designed, constructed, and installed at the 
experimental research station at King Faisal University (latitude $25.4^{\circ} \mathrm{N}$, longitude $49.6^{\circ} \mathrm{E}$, and altitude $142 \mathrm{~m}$ above sea level). The gross dimensions of the solar air heater (greenhouse) were $200 \mathrm{~cm}$ long, $100 \mathrm{~cm}$ wide and $120.87 \mathrm{~cm}$ high at the eaves, with an internal floor surface area of $2.0 \mathrm{~m}^{2}$ as shown in Figure 2. The greenhouse was oriented in an east-west direction to maximize the intensity of the solar radiation. The solar dryer structural frame was formed from an aluminum bar $(5 \mathrm{~cm}$ thick). The rafter length was $57.74 \mathrm{~cm}$, the gable height was $28.87 \mathrm{~cm}$, and the height of each side wall was $92 \mathrm{~cm}$ as shown in Figure 2. The rafters were inclined at $30^{\circ}$ to maximize the solar radiation available inside the solar dryer and to minimize the side effects of wind load on the roof of the solar air heater. Two square timbers (dryer box) made from plywood ( $2.5 \mathrm{~cm}$ thick) were located inside the dryer. The gross dimensions of each square timber were: $1.0 \mathrm{~m}$ long, $100 \mathrm{~cm}$ wide and $30 \mathrm{~cm}$ high, with an internal drying surface area of $1.0 \mathrm{~m}^{2}$. The drying floor was created by placing a wire-netted plate on the upper surface of the square timbers. The space between the wire-netted plate and the bottom of the dryer box formed the air duct. An electric axial fan, $31 \mathrm{~cm}$ in diameter (model Windy DVN-121, Seoul, Korea), was placed in a shelter at one side of the solar dryer. This fan provided variable volumetric rate of drying air of $30 \mathrm{~m}^{3} / \mathrm{min}(1059.4 \mathrm{cfm})$ at a pressure equal to 13 millimeter mercury ( $\mathrm{mm} \mathrm{Hg}$ ), as shown in Fig. (2). An open window positioned at the top of the opposite side was used as an air intake. The window had a surface area of $0.056 \mathrm{~m}^{2}$ ( $0.4 \mathrm{~m}$ long and $0.14 \mathrm{~m}$ wide). The solar greenhouse was covered with a $800-\mu \mathrm{m}$ thick flat fiberglass sheet. Air was cycled through the solar air heater, which heated the air using solar energy, and then moved vertically moved through the dryer box. An air flow rate of 5.5 $\mathrm{m}^{3} / \mathrm{min}$ was employed throughout the experiment.

\subsection{Instruments and data acquisition}

The meteorological data, including the solar radiation flux incident on a horizontal surface (pyranometer), the air temperature as measured with a dry-bulb process (shelter and vented thermistor), the wind speed and direction (cup anemometer and wind van), and the relative humidity of the air (hygrometer), were obtained from the meteorological station which was located approximately $300 \mathrm{~m}$ from the solar greenhouse. To measure the solar radiation flux incident on a horizontal surface inside the solar greenhouse, another pyranometer (Hobo Silicon type, with a measurement range of 0 to $1280 \mathrm{~W} / \mathrm{m}^{2}$ over a spectral range of 0.30 to $1.10 \mu \mathrm{m}$ ) was situated inside the greenhouse. The air temperatures and relative humidity at various locations in the solar greenhouse were measured as shown in Figure 3. The distribution of the air temperatures were measured at heights of 18, 36, 54, and $72 \mathrm{~cm}$ above the bottom of the air chamber. The air stream temperatures in the longitudinal direction of the solar greenhouse were also measured at $40,80,120$, and $160 \mathrm{~cm}$ from the open window to the extracting fan. The time interval for data recording was 60 minutes with data acquisition every 10 seconds for integrated measurements. The mean of 360 scans was recorded on a hard-disk every 60 minutes using a data logging program. A multi-function instrument (Testo 435-2, 40, N.J. 07871, USA) equipped with a hot-wire anemometer probe was used to measure the air velocity and temperature.

\subsection{Mathematical modeling}

The solar greenhouse was operated under quasi steady-state conditions as an air-heating solar collector. In these circumstances, the thermal performance of the solar greenhouse is described by a thermal balance that shows the distribution of the incident solar energy into useful energy gain $\left(\mathrm{Q}_{\mathrm{u}}\right)$, and thermal losses $\left(\mathrm{Q}_{\text {loss }}\right)$, as used by several investigators (Duffie and Beckman, 1991; Bargach, et al., 2000; Shanmugam and Natarajan, 2006; Hossain and Bala, 2007; Abdellatif, et al., 2010). The heat energy balance can be computed as follows:

$$
Q=Q_{U}+Q_{\text {loos }}, \quad \text { Watt }
$$

The solar energy available inside the solar dryer $(\mathrm{Q})$ could be calculated in terms of the solar radiation that penetrated the cover and the net surface area of the dryer as:

$$
Q=R+A_{d}, \quad \text { Watt }
$$

where $\mathrm{R}$ is the total solar radiation flux incident on a horizontal surface inside the solar dryer $\left(\mathrm{W} / \mathrm{m}^{2}\right)$, and $A_{d}$, is the net surface area of the drying box $\left(\mathrm{m}^{2}\right)$. The useful heat gain by a dryer can be expressed as:

$$
Q_{u}=m_{a} C_{p}\left(T_{a o}-T_{a m}\right), \quad \text { Watt }
$$

where $m_{a}$ and $C_{P}$, respectively, are the air flow rate $(\mathrm{kg} / \mathrm{s})$ and the specific heat of the air $\left(\mathrm{J} / \mathrm{kg}{ }^{\circ} \mathrm{C}\right), \mathrm{T}_{\mathrm{am}}$ is the ambient air temperature outside the dryer $\left({ }^{\circ} \mathrm{C}\right)$, and $\mathrm{T}_{\mathrm{ao}}$ is the outlet air temperature (exhaust air) of the solar dryer $\left({ }^{\circ} \mathrm{C}\right)$. A measure of the thermal performance of the solar dryer is the overall thermal efficiency $\left(\eta_{\circ}\right)$, defined as the ratio of useful heat gain over any time period to the incident solar radiation over the same period. 


$$
\eta_{o}=\frac{Q_{u}}{R A_{d}} \times 100 \quad, \quad \%
$$

The total heat losses from inside the solar dryer to the outside by conduction and convection, air exchange, and thermal radiation can be computed from the following formula:

$$
Q_{\text {loos }}=q_{c}+q_{r}, \quad \text { Watt }
$$

The heat losses from the solar dryer by conduction and convection can be determined by limiting the heat transfer to conduction and convection., if the overall heat transfer coefficient $\left(U_{o}\right) \mathrm{in} \mathrm{W} / \mathrm{m}^{2{ }^{\circ}} \mathrm{C}$, the total surface area of the solar dryer cover $\left(\mathrm{A}_{\mathrm{c}}\right)$ in $\mathrm{m}^{2}$, and the air temperature difference between the inside $\left(\mathrm{T}_{\mathrm{av}}\right)$ and outside ambient air $\left(\mathrm{T}_{\mathrm{am}}\right)$ in ${ }^{\circ} \mathrm{C}$ are known or measured. The procedure does not require the separation of the conduction and convection components. It can be calculated from the following equation:

$$
q_{c}=U_{o} A_{c}\left(T_{a v}-T_{a m}\right), \text { Watt }
$$

The heat energy loss by thermal radiation $\left(\mathrm{q}_{\mathrm{r}}\right)$ can be computed using the mean emittance factor of the inside substances $(\varepsilon)$, the average transmissivity coefficient at long-wave radiation $(\tau)$, the Stefen-Boltzmann constant $(\sigma)$ in $\mathrm{W} / \mathrm{m}^{2} \mathrm{~K}^{4}$, and the absolute temperature difference between the inside air and the sky $\left(\mathrm{T}_{\text {sky }}\right)$ in ${ }^{\circ} \mathrm{K}$, as

$$
\begin{gathered}
q_{r}=\varepsilon \tau \sigma A_{f}\left(T_{a v}^{4}-T_{s k y}^{4}\right), \text { Watt } \\
T_{s k y}=0.0552\left(T_{a m}\right)^{1.5}, \quad{ }^{\mathrm{o}} \mathrm{K}
\end{gathered}
$$

The normalized temperature increase $\left(\mathrm{D}_{\mathrm{T}}\right)$ of the solar dryer is the difference between the average inside and outside ambient air temperatures divided by the solar radiation flux incident inside the dryer. It can be computed by the following relationship:

$$
D_{T} \frac{\left(T_{a v}-T_{a m}\right)}{R}, \quad \mathrm{~m}^{2}{ }^{\circ} \mathrm{C} / \mathrm{W}
$$

A Microsoft Excel ${ }^{\circledR}$ worksheet has been developed and used for computing the thermal performance of the solar dryers using the previous equations. The worksheet has two input sets of data: one contains the constant parameters (Table 1), and the other contains the input data (Table 2). The worksheet outputs data are also listed in Table 2.

Data were measured and stored in microcomputer files and statistically analyzed using an Excel program. A significance level of 0.05 was conventionally accepted as the minimum level of significance. If higher levels of significance were found, these values were included in the text $(\mathrm{P} \leq 0.01$ and $\mathrm{P} \leq 0.001)$.

\section{Results and Discussion}

During the experimental period (October 2010), the solar greenhouse was operated satisfactorily for 5 days. The thermal efficiency of the solar greenhouse can be evaluated based on the thermal performance analysis. The thermal performance analysis of the solar greenhouse depends upon the geometric characteristics of the greenhouse (dryer), the mass flow rate of the operating fluid (air), and the climatic conditions surrounding the greenhouse. The climatic conditions were associated with the intensity of solar radiation, ambient air temperature, and wind speed. During the experimental period, there were 60 hours of bright sunshine of which 55 hours were used in the thermal performance analysis. The hourly average solar energy flux incident outside and inside the solar greenhouse (solar dryer) during the experimental period is plotted in Figure 4. The actual solar radiation ranged from near zero to about $1000 \mathrm{~W} / \mathrm{m}^{2}$ within the $12 \mathrm{hrs}$ of daylight. The lowest values during the experimental period ranged from $25-105 \mathrm{~W} / \mathrm{m}^{2}$, just after sunrise and prior to sunset. The values varied from hour to hour during the experimental period due to the sky cover (clouds), the solar altitude angle, and the solar incident angle. Therefore, the thermal performance analysis was tested only through eleven hours (from 7 am to $5 \mathrm{pm}$, solar time). The actual solar radiation recorded inside the solar greenhouse was lower than that outside of the greenhouse because of the reflectivity, absorptivity, and transmissivity of the greenhouse covering material. The hourly average solar radiation recorded outside and inside the solar greenhouse was 672.6 and $560.7 \mathrm{~W} / \mathrm{m}^{2}$, respectively, with the flat fiberglass sheet transmittance of $77.48 \%$. To determine the amount of solar radiation penetrating the solar greenhouse cover $\left(\mathrm{R}_{\mathrm{i}}\right)$ as a function of the actual solar radiation flux incident outside $\left(\mathrm{R}_{\mathrm{o}}\right)$, all the data recorded during the experimental period were plotted in Figure 5. Regression analysis revealed a highly significant linear relationship $(\mathrm{r}=0.989 ; \mathrm{P} \leq 0.001)$ between these parameters. The regression equation for the best fit was:

$$
R_{i}=0.7748\left(R_{o}\right)
$$




\subsection{Solar Energy Available Inside the Solar Dryer}

The daily average solar energy available inside the solar greenhouse (dryer) during the experimental period was $12.335 \mathrm{kWh}$. Because the solar energy available inside the solar greenhouse is the main source of energy used in the drying process of agricultural products, this energy strongly affected the increase in temperature of the drying air and may be considered a very important parameter affecting the drying process. The hourly average air temperature inside the solar greenhouse was $47.7^{\circ} \mathrm{C}$, while the outside air temperature was $33.6^{\circ} \mathrm{C}$. Accordingly, the compiled data showed that the solar greenhouse (dryer) increased the interior air temperature by $14.1{ }^{\circ} \mathrm{C}$ and reduced the air relative humidity $(35.3 \%)$ by $9.6 \%$ compared to the outside air. We observed a sinusoidal variation of the air temperature with solar time. The air temperature in the solar greenhouse varied from 27.0 to $52.5^{\circ} \mathrm{C}$. The diurnal variation amplitude of the solar greenhouse was more significant. The maximum air temperatures during the experimental period reached $52.5^{\circ} \mathrm{C}$ at approximately noon. At nighttime, the air temperatures inside the solar greenhouse were almost equal to the outside air temperatures, while during the daylight, the air temperatures were usually greater than the outside temperatures.

\subsection{Useful heat gain and heat losses}

The daily average useful heat gain by the solar greenhouse during the experimental period was $7.414 \mathrm{kWh}$. The amount of useful heat acquired varied from hour to hour and varied daily during the experimental period due to the variations in solar energy available, the ambient air temperature surrounding the solar greenhouse, and the wind speed (Nelson, 2011). As the ambient air temperature increased, the difference in temperature between the hot air inside and the air passing through the solar dryer decreased, and the useful heat gain was reduced. During the experimental period, the useful heat gain was approximately $60.11 \%$ of the solar radiation available inside the solar greenhouse. Consequently, $39.89 \%$ of the solar radiation available inside the solar greenhouse was lost by conduction, convection and radiation. The daily average heat losses by conduction and convection from the solar greenhouse were $3.947 \mathrm{kWh}$ while the heat energy lost due to thermal radiation was $0.686 \mathrm{kWh}$. These values varied from hour to hour and day to day due to the ambient air temperature, the wind speed, and the temperature difference between inside and outside the solar greenhouse. As the air temperature inside the solar greenhouse increased above the ambient air temperature, the air temperature difference between the inside and outside increased while the heat losses increased and vice versa.

\subsection{Overall Thermal Efficiency}

The overall thermal efficiency is the ratio of the useful heat gain to the solar energy available inside the solar greenhouse. The daily average overall thermal efficiencies of the solar greenhouse during the experimental period were $60.11 \%$ and $39.89 \%$ of the solar energy available inside the solar greenhouse was lost. The overall thermal efficiency $\left(\eta_{\mathrm{o}}\right)$ for the solar greenhouse was plotted against the normalized temperature increase $\left(D_{T}\right)$ as shown in Figure 6. Regression analysis revealed a highly significant linear relationship $(r=-0.999 ; \mathrm{P} \leq 0.001)$ between these parameters. The regression equations for the best fit were:

$$
\eta_{o}=06840-3.6623\left(D_{T}\right)
$$

The regression analysis also showed that the overall thermal efficiency of the solar greenhouse dryer can be expressed as:

$$
\begin{aligned}
\eta_{o}=\frac{Q_{u}}{Q}= & F_{R}\left(\eta_{o p}\right)-F_{R} U_{o} \frac{\left(T_{a v}-T_{a m}\right)}{R} \\
\eta_{o}= & F_{R}\left(\eta_{o p}\right)-F_{R} U_{o}\left(D_{T}\right) \\
& \eta_{o}=a-F_{R} U_{o}\left(D_{T}\right)
\end{aligned}
$$

The regression equation is definitely the numerical expression of equation (13). The y-intercept (a) equals the product of the heat removal factor $\left(F_{R}\right)$ and the optical efficiency $\left(\eta_{o p}\right)$. The slope equals the product of the heat removal factor and the overall heat transfer coefficient $\left(\mathrm{U}_{\mathrm{O}}\right)$. The plot of overall thermal efficiency versus the normalized temperature increase was a straight line with a y-intercept $F_{R}\left(\eta_{o p}\right)$ and slope $\left(-F_{R} U_{O}\right)$. It is clear that $\mathrm{U}_{\mathrm{O}}$ is a function of the temperature difference between the inside and outside air, the mass flow rate of the air, and the wind speed. The heat removal factor is also a weak function of the overall heat transfer coefficient. Some variations were seen in the relative proportions of the beam and the diffuse components of solar radiation. Therefore, some scatter in the data was expected due to the temperature dependence and mass flow rate effects as shown in Figure 6. The previously obtained data agrees with the data published by Duffie and Beckman (1991) and ASHREA (2005). 


\subsection{Heat Energy Balance on the Solar Greenhouse}

The mathematical model of the thermal balance of the solar greenhouse was used to predict the solar energy available inside the solar dryer in terms of the summation of the useful heat gain and the total heat losses from the solar greenhouse. Many factors affect the thermal balance of a solar greenhouse during daylight. These factors and their effects on the thermal balance were as follows: the solar radiation available inside that was converted into useful heat gain, the forced convection heat transfer coefficient, the variation in the air temperatures in the solar greenhouse, and the ambient air temperature surrounding the solar greenhouse. Therefore, it is imperative to determine the available solar energy to check whether there are differences between the actual heat energy gained and lost and to determine the heat energy required to increase the drying air temperature inside the solar greenhouse (dryer). The predicted heat energy gained and lost was plotted as a function of the measured solar energy available inside the greenhouse as shown in Figure 7. The predicted heat energy for the solar greenhouse was well validated with that measured during the experimental period $(\mathrm{r}=0.999)$ and showed an excellent agreement.

\section{Conclusion}

The primary objective of this solar greenhouse (dryer) was to increase the amount of solar radiation converted into useful heat gain and to investigate effective uses of that heat gain to increase the drying air temperature. For the duration of this research work, the solar energy available was considered to be the most important parameter affecting thermal performance of the solar greenhouse. The useful heat gain and normalized air temperature increase were found to be affected mainly by the solar energy available and the mass flow rate of the drying air. The daily average solar energy available inside the solar greenhouse during the experimental period was 12.335 $\mathrm{kWh}$, and $7.414 \mathrm{kWh}$ of that converted into useful heat gain. The daily average overall thermal efficiency of the solar greenhouse during the experimental period was $60.11 \%$. Consequently, $39.89 \%$ of the solar energy available inside the solar greenhouse was lost. The predicted heat energy for the solar greenhouse was well validated with that measured during the experimental period $(\mathrm{r}=0.999)$ and showed an excellent agreement.

\section{References}

Abdellatif, S.M., Yousef, A.T., Ghada M., \& Mosad, A. (2010). Utilization of solar tunnel greenhouse as a solar drier for drying seedless grapes. Journal of Soil Sciences and Agricultural Engineering, Mansoura University, 1(4), 363-377.

Aboul-Enein, S., El-Sebaii, A. A., Ramadan, M. R. I., \& El-Gohary, H. G. (2000). Parametric study of a solar air heater with and without thermal storage for solar drying applications. Renewable Energy, 21, 506-22. http://dx.doi.org/10.1016/S0960-1481(00)00092-6

Al-Amri A. M. S. (1997). Thermal performance tests of solar dryer under hot and humid climatic conditions. AMA, Japan, 28(3), 56-60.

ASHREA. (2005). Handbook Fundamentals, American Society of Heating, Refrigerating and Air conditioning Engineers, Atlanta, GA, USA.

Bargach, M. N., Tadili, R., Dahman, A. S. \& Boukallouch, M. (2000). Survey of thermal performances of a solar system used for heating of agricultural greenhouses in Morocco, Renewable Energy, 20, 415-433. http://dx.doi.org/10.1016/S0960-1481(99)00118-4

Dincer, I. (1999). Environmental impacts of energy. Energy Policy, 27(14), 845-854. http://dx.doi.org/10.1016/S0301-4215(99)00068-3

Duffie, J. A. \& Beckman, W. A. (1991). Solar engineering of thermal processes. John Wiley and Sons, New York, USA.

Ekechukwu, O. V., \& Norton, B. (1999a). Review of solar-energy drying systems, II: an overview of solar drying technology. Energy Conversions Manage; 40(6), 615-655. http://dx.doi.org/10.1016/S0196-8904(98)00093-4

Ekechukwu, O. V., \& Norton, B. (1999b). Review of solar-energy drying systems, III: low temperature air-heating solar collectors for crop drying applications. Energy Conversions Manage, 40(6), 657-671. http://dx.doi.org/10.1016/S0196-8904(98)00094-6

Ekechukwu, O.V. (1999). Review of solar-energy drying systems. I: an overview of drying principles and theory. Energy Conversions Manage, 40(6), 593-613. http://dx.doi.org/10.1016/S0196-8904(98)00092-2

Hossain, M. A., \& Bala, B. K. (2007). Drying of hot chili using solar tunnel drier. Solar Energy, 81, 85-92. http://dx.doi.org/10.1016/j.solener.2006.06.008 
Hossain, M. A., \& Gottschaslk, K. (2006). Determination of optimum conditions for half fruit drying kinetics of tomato. Bornimer Agric. Berichte, 55, 181-97.

Jain, D. \& Jain, R. K. (2004). Performance evaluation of an inclined multi-pass solar air heater with in-built thermal storage on deep-bed drying application. J. Food Eng., 65, 497-509.

Jairaj, K. S, Singh, S. P., \& Srikant, K. (2009). A review of solar dryers developed for grape drying. Solar Energy, 83:1698-1712. http://dx.doi.org/10.1016/j.solener.2009.06.008

Joshi, C. B., Gewali, M. B. \& Bhandari, R. C. (2004). Performance of solar drying systems: A case study of Nepal. International Energy Journal, 85, 53-57.

Koyuncu, T. (2006). Performance of various design of solar air heaters for crop drying applications. Renewable Energy, 31, 1073-88. http://dx.doi.org/10.1016/j.renene.2005.05.017

Montero I., Blanco, J., Miranda,T., Rojas, S. \& Celma, A. R. (2010). Design, construction and performance testing of a solar dryer for agro-industrial by-products. Energy Conversion and Management, 51, 1510-1521. http://dx.doi.org/10.1016/j.enconman.2010.02.009

Montero, I. (2005). Modeling and construction of hybrid solar dryer for biomass byproducts. $\mathrm{PhD}$ thesis, Department of Chemical and Energetic Engineering, University of Extremadura, Spain.

Nelson, V. P. (2011). Greenhouse operation and management. (7th Edition). New York, USA: Prentice Hall, Inc. Englewood Cliffs.

Sarsavadia, P. N. (2007). Development of a solar-assisted dryer and evaluation of energy requirement for the drying of onion. Renewable Energy, 32, 2529-2547. http://dx.doi.org/10.1016/j.renene.2006.12.019

Sethi, V. P., \& Sharma, S. K. (2007). Survey of cooling technologies for worldwide agricultural greenhouse applications. Solar Energy, 81 (12), 1447-1459. http://dx.doi.org/10.1016/j.solener.2007.03.004

Sethi, V.P. (2009). On the selection of shape and orientation of a greenhouse: thermal modeling and experimental validation. Solar Energy, 83 (1), 21-38. http://dx.doi.org/10.1016/j.solener.2008.05.018

Shanmugam, V. \& Natarajan, E. (2006). Experimental investigation of forced convection and desiccant integrated solar dryer. Renewable Energy, 31, 1239-1251. http://dx.doi.org/10.1016/j.renene.2005.05.019

Sharma, A., Chen, C. R., \& Vu Lan, N. (2009). Solar energy drying system: A review. Renewable and Sustainable Energy Review, 13, 1185-1210. http://dx.doi.org/10.1016/j.rser.2008.08.015

Timoumi, S., Mihoubi, D. \& Zagrouba. (2004). Simulation model for a solar drying process. Desalination, 168, 111-115. http://dx.doi.org/10.1016/j.desal.2004.06.175

Vlachos, N. A, Karapantsios, T. D., Balouktsis, A. I. \& Chassapis, D. (2002). Design and testing of a new solar tray dryer. Dry Technology, 20(6), 1243-1271.

Table 1. Constant parameters and variables required as inputs

\begin{tabular}{|l|c|}
\hline Configuration of file inputs: & Value \\
\hline Floor surface area of the solar greenhouse $\left(\mathrm{A}_{\mathrm{d}}\right), \mathrm{m}^{2}$ & 2.00 \\
\hline Overall heat transfer coefficient $\left(\mathrm{U}_{\mathrm{o}}\right), \mathrm{W} / \mathrm{m}^{2}{ }^{\circ} \mathrm{C}$ & 6.80 \\
\hline Specific heat of operating fluid, air $\left(\mathrm{C}_{\mathrm{P}}\right), \mathrm{J} / \mathrm{kg}{ }^{\circ} \mathrm{C}$ & 1006.6 \\
\hline Cover surface area of the solar greenhouse $\left(\mathrm{A}_{\mathrm{c}}\right), \mathrm{m}^{2}$ & 4.01 \\
\hline Transmissivity coefficient at long-wave radiation $(\tau)$, decimal & 0.43 \\
\hline Mean emittance factor of the cover $(\varepsilon)$, decimal & 0.77 \\
\hline Mass flow rate of air $\left(\mathrm{m}_{\mathrm{a}}\right), \mathrm{kg} / \mathrm{s}$ & 0.6160 \\
\hline Stefen-Boltzmann constant $(\boldsymbol{\sigma}), \mathrm{W} / \mathrm{m}^{2} \mathrm{~K}^{4}$ & $5.67 \times 10^{-8}$ \\
\hline
\end{tabular}


Table 2. Inputs data required to for calculations together with outputs data.

\begin{tabular}{|c|c|}
\hline Inputs data: & Outputs data: \\
\hline $\begin{array}{l}\text { Solar radiation flux incident inside the solar greenhouse (R), } \\
\mathrm{W} / \mathrm{m}^{2}\end{array}$ & - Solar energy available inside (Q), Watt \\
\hline $\begin{array}{l}\text { Ambient air temperature or inlet into the solar greenhouse } \\
\left(\mathrm{T}_{\mathrm{am}}\right),{ }^{\circ} \mathrm{C}\end{array}$ & - Useful heat gain, $\left(\mathrm{Q}_{\mathrm{u}}\right)$, Watt \\
\hline - $\quad$ Outlet air temperature from the solar greenhouse $\left(\mathrm{T}_{\mathrm{ao}}\right),{ }^{\circ} \mathrm{C}$ & $\begin{array}{l}\text { - Heat energy losses by conduction and convection }\left(\mathrm{q}_{\mathrm{c}}\right) \text {, } \\
\text { Watt }\end{array}$ \\
\hline - $\quad$ Average air temperature inside the solar greenhouse $\left(\mathrm{T}_{\mathrm{av}}\right),{ }^{\circ} \mathrm{C}$ & - $\quad$ Sky temperature $\left(\mathrm{T}_{\text {sky }}\right),{ }^{\circ} \mathrm{K}$ \\
\hline & - Heat energy losses by thermal radiation $\left(\mathrm{q}_{\mathrm{r}}\right)$, Watt \\
\hline & $\begin{array}{l}\text { - Total heat losses from the solar greenhouse }\left(\mathrm{Q}_{\text {loss }}\right) \text {, } \\
\text { Watt }\end{array}$ \\
\hline & - Overall thermal efficiency, $\left(\eta_{\mathrm{o}}\right), \%$ \\
\hline & - $\quad$ Normalized temperature rise $\left(\mathrm{D}_{\mathrm{T}}\right), \mathrm{m}^{2}{ }^{\circ} \mathrm{C} / \mathrm{W}$ \\
\hline
\end{tabular}

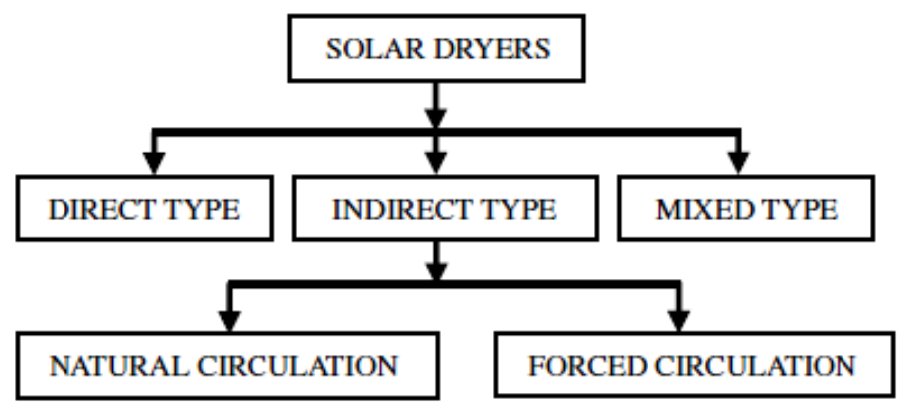

Figure 1. Classification of solar dryer types (Jairaj et al., 2009)

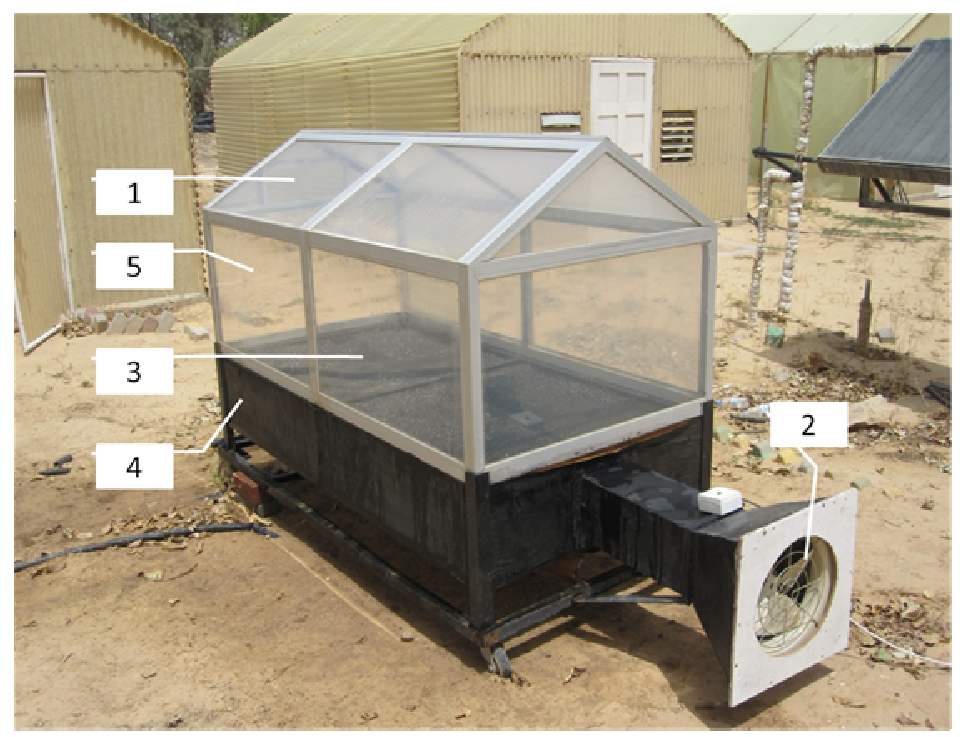

Figure 2. Solar air heater (solar dryer-greenhouse type); (1) Window (air intake); (2) Extracting fan; (3) Wire- netted floor; (4) Air chamber; and (5) Fiberglass cover 


\section{Sensor}
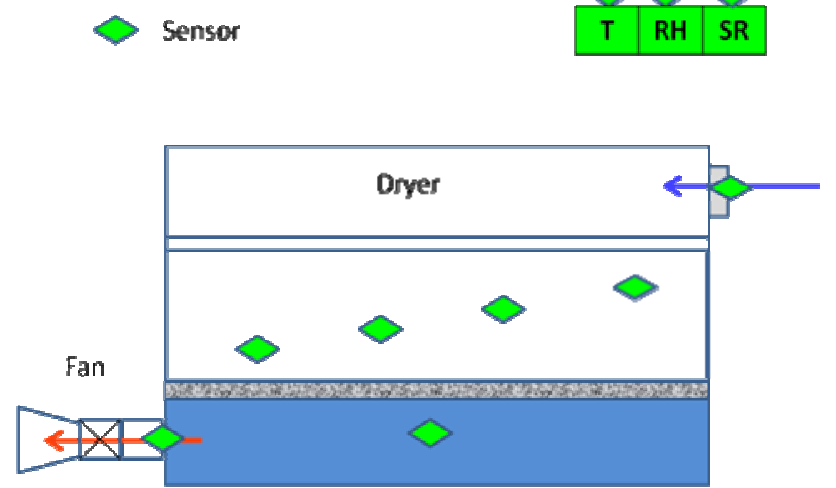

Figure 3. The measurements of air temperature and air relative humidity at various locations in the solar greenhouse

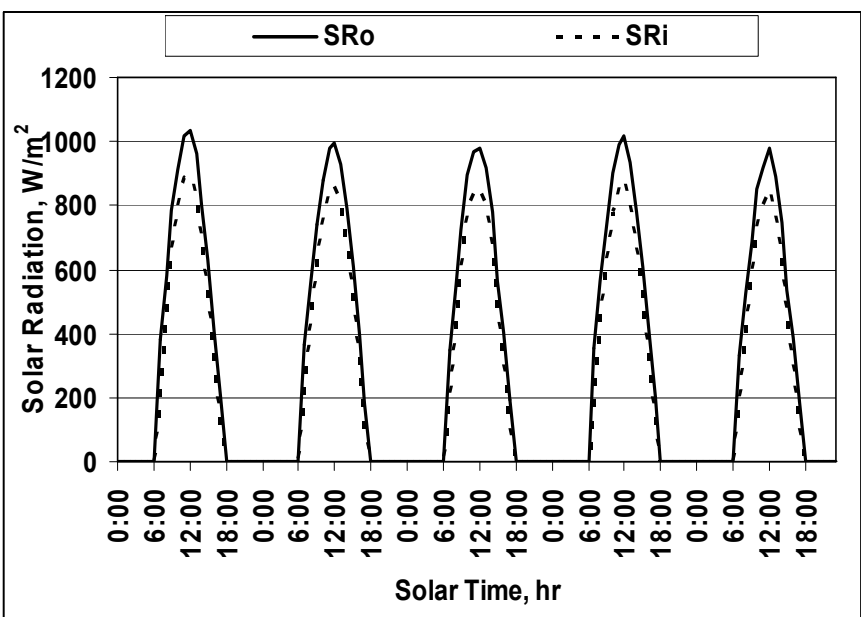

Figure 4. Hourly average solar radiation flux incident outside and inside the solar tunnel greenhouse dryer during the experimental period

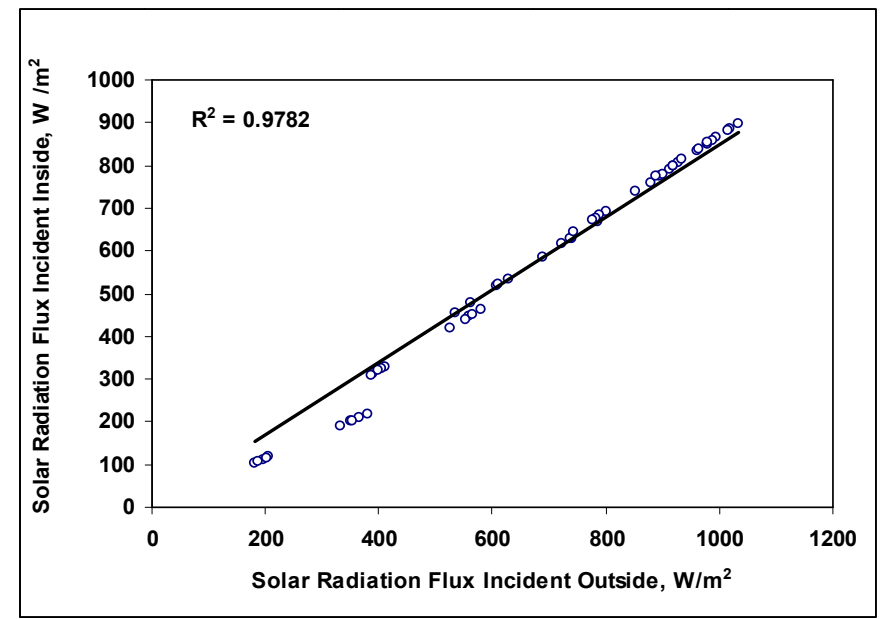

Figure 5. The hourly average solar radiation flux incident inside the solar dryer versus the solar radiation outside 


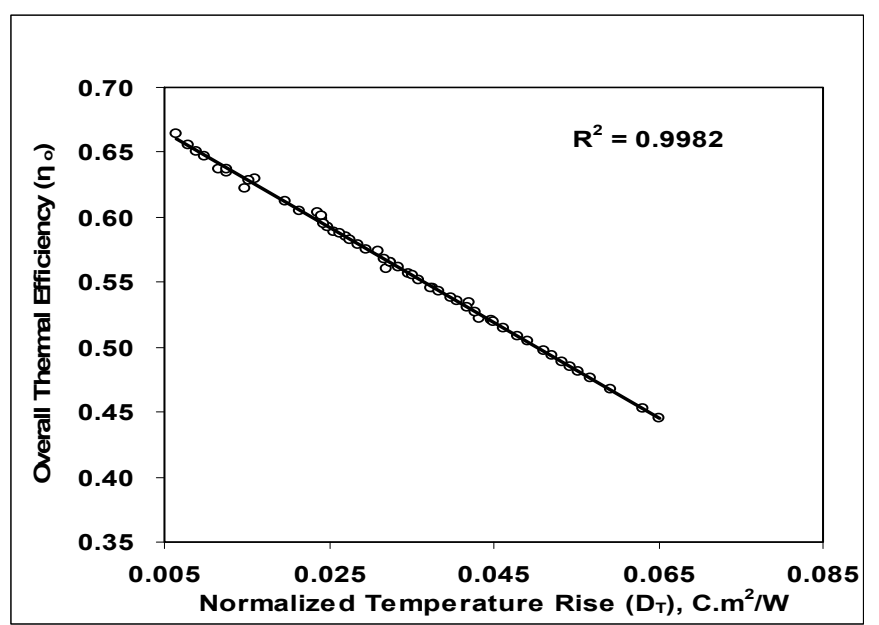

Figure 6. The overall thermal efficiency $\left(\eta_{\mathrm{o}}\right)$ for the solar greenhouse was plotted against the normalized temperature increase $\left(D_{T}\right)$

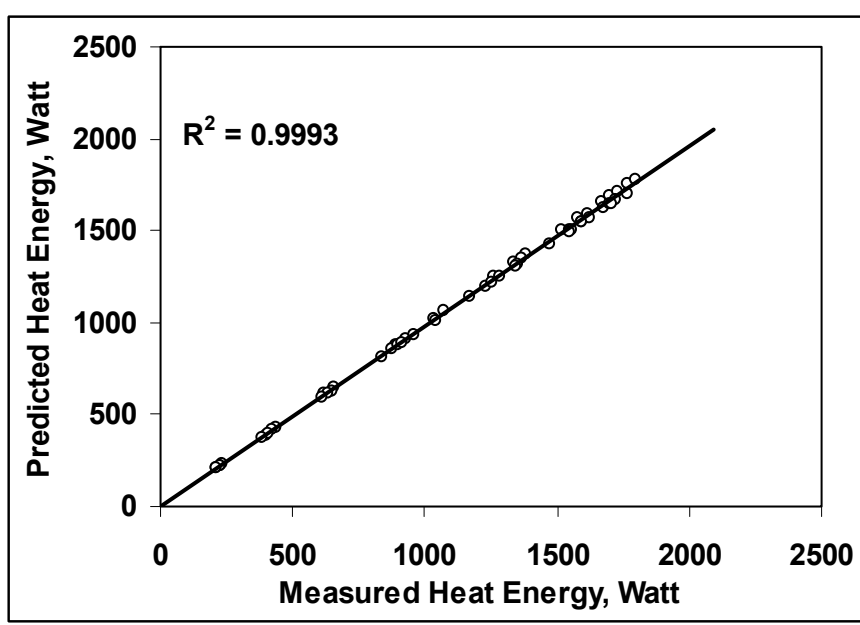

Figure 7. The predicted heat energy gained and lost versus that measured for the three solar tunnel greenhouse dryers 